Comparison of I ef $t$ ventricular outflow geometry and aorti $c$ val ve area in patient $s$ wi th aortic stenosi s by 2-di mensi onal versus 3- di mensi onal echocar di ogr aphy

\begin{tabular}{|l|l|}
\hline 著者 & 齊藤 岳児 \\
\hline 発行年 & $2013-06-21$ \\
\hline URL & ht t p: //hdl . handl e. net /10271/2696 \\
\hline
\end{tabular}


博士 (医学) 齊藤岳児

論文題目

Comparison of left ventricular outflow geometry and aortic valve area in patients with aortic stenosis by 2-dimensional versus 3-dimensional echocardiography

(2次元と3次元心エコーによる大動脈弁狭窄症患者での左室流出路形態と大動脈弁口面積の比 較)

論文の内容の要旨

[はじめに

大動脈弁狭窄症患者は年々増加し、最近では開胸術ではない経皮的大動脈弁置換術が欧米 を中心に行われてきており、日本でも治験が開始されて注目されている。大動脈弁狭窄症に侵襲 的治療介入を行うのは重度の患者であり、その重症度決定には心臓エコーを用いて判断すること になっている。その際、弁口面積で $<1.0 \mathrm{~cm}^{2}$ もくは平均圧較差 $>40 \mathrm{mmHg}$ であることが重症と判 定する基準となっている。しかし、2 次元心エコーでは正確な測定ができていない可能性があり、3 次元心エコーを用いることによって大動脈弁周囲の形態を正確に評価し(特に楕円の形態)、的確 な重症度診断ができる可能性がある。

[患者ならびに方法］

2 次元経胸壁心エコーで計測し、弁口面積が $<2.0 \mathrm{~cm}^{2}$ の大動脈弁狭窄症患者 49 症例を対象 とした。そのうち、中等度以上の大動脈弁閉鎖不全症 $(\mathrm{N}=3)$ や僧房弁閉鎖不全症 $(\mathrm{N}=4)$ を合併し た症例、 3 次元で明瞭な画質が得られなかった症例 $(\mathrm{N}=2)$ を除いた 40 例を解析した。症例に対し て、2 次元経胸壁心エコー (2D-TTE: 2-dimensional transthoracic echocardiography)、 2 次元経食 道心エコー (2D-TEE: 2-dimensinal transesophageal echocardiography)、 3 次元経食道心エコー (3D-TEE: 3-dimensional transesophageal echocardiography)を施行した。2 次元心エコーで面積を 求める際には $\pi \times(\text { 半径 })^{2}$ を用い 3 次元心エコーでは左室流出路の前後径、内外側径、楕円率 (前後径/内外径) とトレース計測した面積(プラニメトリー法)を測定計算した。さらに、2D-TTEによ る連続の式を用いて、左室流出路径から大動脈弁口面積 $(=$ 左室流出路の面積 $\times$ 左室流出路部 の時間速度積分／大動脈弁口部の時間速度積分)を求め、3D-TEE での連続の式の值と比較し た。また、可能な症例では、 2 次元 3 次元各々において連続の式で求めた大動脈弁口面積とプラ ニメリー法で測定した実測值との比較をした。最後に左室流出路の形態が楕円となる要素を解析 した。

[結果]

左室流出路の径は、2D-TTE で $2.2 \mathrm{~cm}$ (2.0-2.3, 25 パーセンタイル-75パーセンタイル)、2D-TEE で $2.2 \mathrm{~cm}$ (2.0-2.3)、3D-TEE の前後径で $2.1 \mathrm{~cm}$ (2.0-2.3)、内外側径で $2.7 \mathrm{~cm}$ (2.4-3.0) であり、そ の棈円率は $0.80 \pm 0.08$ (平均土標準偏差) であった。左室流出路面積は、2D-TTE で $3.7 \mathrm{~cm}^{2}$ (3.1-4.1)、2D-TEE で $3.7 \mathrm{~cm}^{2}$ (3.1-4.0)、3D-TEE で $4.6 \mathrm{~cm}^{2}$ (3.9-5.3, p<0.05 vs. 2D-TTE、2D-TEE) で、 2 次元心エコーでの左室流出路面積は 3 次元心エコーに比して過小評価されていた。また、 連続の式で求めた大動脈弁口面積は、2D-TTE で $0.77 \mathrm{~cm}^{2}$ (0.64-0.94)、2D-TEE で $0.76 \mathrm{~cm}^{2}$ (0.62-0.95) であったのに比し、3D-TEE では $1.0 \mathrm{~cm}^{2}$ (0.79-1.3、p<0.05 vs. 2D-TTE、2D-TEE) と、 
2 次元心エコーでの大動脈弁口面積は 3 次元心エコーに比して過小評価されていた。さらに、 2D-TTE と 2D-TEE での連続の式から求めた大動脈弁口面積は、プラニメリリー法による弁口面積 と比して過小評価され、それに対して 3D-TEE では連続の式とプラニメトリー法で求めた弁口面積 との間で有意差を認めなかった。

\section{[考察 $]$}

現在、欧州・米国・日本におけるガイドラインでは、 2 次元心エコーによる大動脈弁狭窄症評価 が推奨されている。しかし、石灰化の強い大動脈弁狭窄症では直接弁口面積を計測することが困 難であることが多く、左室流出路面積を用いた連続の式で計測されている。2 次元心エコーで計測 すると、左室流出路が円であると仮定され、 $\pi \times(\text { 左室流出路半径 })^{2}$ で計算されている。しかし、当 研究の結果により左室流出路は楕円であり、正確な面積を測定するには 3 次元心エコーでしか行 えない。今後、3D エコーを用いることにより、大動脈弁狭窄症の重症度が適切に評価され、適切な 時期に開胸手術・インターベンションが施行されていくことが可能と考えられる。実際に、当研究で は連続の式で重度大動脈弁狭窄症とされていた患者の $1 / 3$ が中等症とされた。

最近では、心臓CTやMRIにより左室流出路形態の評価ができるようになっている。しかし、腎機 能が悪い患者にはCTを用いることができず、ペースメーカーが植え込まれている患者にはMRIを 用いて評価することが困難であり、依然として心エコーを用いた大動脈弁評価が重要であり、特に 3 次元心エコーの活用が重要と考えられる。

\section{[結論 $]$}

3 次元心エコーは比較的簡便な方法であり、大動脈弁狭窄症の評価に用いられるのが好ましい。 